\title{
FACTORS AFFECTING STUDENT'S ENTREPRENEURIAL INTENTIONS IN PALU, CENTRAL SULAWESI, INDONESIA
}

\author{
Bachri Syamsul, Adda Harnida W. \\ Department of Economics, University of Tadulako, Indonesia \\ *E-mail: syamsulbachri09@gmail.com
}

\begin{abstract}
The increasing number of graduates and reliance on the formal employment creates limited spaces in the formal employment market. To avoid unemployment, graduates need to strategically plan their future. Entrepreneurship is one of employment options for students after graduating. Developing strategy to increase self-reliance, creativity, initiative, and innovations in business among university graduates is needed to reduce dependence on formal labor sector. This research aims to identify factors affecting entrepreneurial intentions of students in Tadulako University, Palu. By applying a survey method with qualitative descriptive approach based on secondary data and primary data include questionnaires, interviews, and observations, this study classifies some factors developed based on dimensions such as the need for achievement, self-efficacy, entrepreneurship education, and gender stereotypes. The identification of factors influencing entrepreneurial interest among students is an important step considering that $74.9 \%$ of respondents said they would seek work after completing the study, $12.9 \%$ would continue their studies, $10.9 \%$ did not make choices, and $1.3 \%$ decided not to enter the job market after completing the study.
\end{abstract}

\section{KEY WORDS}

Entrepreneurships, entrepreneurial intention, achievement, self-efficacy.

Palu City is a region with abundant natural resources that can be developed through entrepreneurial activities. These resources can be beneficial if managed efficiently and effectively. To achieve this, it is necessary for the initiative and creativity of the younger generation to utilize and maintain the available local resources. However, the problem arises when the intention of managing these resources through entrepreneurial practices is relatively low. For university students as future generations, they need stimulants to leverage their managerial skills to work independently and participate as active economic actors.

Formal education is not a guarantee for people to enter the employment sector. The higher one's education, the higher probability of becoming unemployed because of the gap between the education and expected skills, and also limitation of employment (Darmaningtyas 2008; Adda, et.al, 2014). Interestingly, graduates' reliance on the formal sector is still high. Formal employment (work as employees in private and government institutions) is still their primary target after graduating.

This in turn, contributes to the increasing number of unemployment. A series of programs and activities should be endorsed to prevent the higher rate of educated unemployment among the youth. Entrepreneurial activity (self-employment) provides opportunities for the potential labor force to create or open a job and manage it independently. The habit of hardworking and the nature of risk-taking facilitates the job seekers to optimize their potentials. Entrepreneurship assumed as one of the factors that determine and be a motivating factor in achieving economic development and job creation. In order to improve their attitude towards this idea, it is required an appropriate model to enhance understanding of college students on how to develop and to encourage their willingness to engage in entrepreneurship. Prior developing a model to develop their entrepreurial intentions, it is necessary to explore factors that potentially affecting their intentions to engage in self-employment.

Entrepreneurial intentions can be influenced by factors such as the need for achievement, self-efficacy, entrepreneurship education, and gender stereotypes. In addition, 
personal characteristics and traits, educational factors, demographic factors, social and cultural factors also contributed to the development of entrepreneurial interests (Friedman et.al, 2012). This research is a preliminary stage in building an integrated model based on the model developed by Krueger, Reilly, and Carsrud (2000) to measure the level of student entrepreneurship intention. The model is hoped to be developed and modified based on the characteristics of students in Palu, Central Sulawesi to reduce their reliance on formal sector employment.

\section{LITERATURE REVIEW}

Entrepreneurial Intentions. Research indicates that entrepreneurial intentions play a significant role in the decision to practice entrepreneurship (Linan, 2004; Kolvereid, L., \& Isaksen, E. 2006; Kautonen, Tornikovski, Kibler, 2011; Ozaralli and Rivenburgh, 2016). Entrepreneurial intention is the tendency of a person to perform or not perform a behavior for a specific purpose. The intention encourages the young generation to start and establish an independent business and committed in its management (Krueger, Reilly, and Carsrud, 2000; Indarti and Rostiani, 2008; Lakovleva, et.al, 2011).

Entrepreneurial intention is strongly related to the theory of planned behavior (TPB) that is developed by Ajzen (1991) that includes a dimension of perceived behavioral control (PBC). Intentions models enable the exploration of various triggers of a business emergence and its impacts, identify influences emergence, and how to perform the behavior (Krueger and Carsrud, 1993). The strong desire for entrepreneurship supported by entrepreneurship programs that can be learned and mastered. This makes entrepreneurship a viable alternative employment and career choice for college graduates.

One of the factors that drive the behavior of entrepreneurs is their desire to do something new through independent business. This desire by Ajzen and Fishbein (1975) referred to as a booster components from within the individual who refers to the desire to perform a certain behavior. The idea of intention underlines internal flesh of an act that is influenced by various conditions. Then, Bird (1988) emphasizes the idea and argued that the intention is a condition of mind which directs one's attention (thoughts and actions) towards the object (goal) or a certain path in order to achieve something. Intention is an important part in the theory of reasoned action and a successful predictor of behavior, because it connects between attitudes and behavior. Thus, the intention may be viewed as a special part of the individual as an object of belief and behavior as attribution (Ajzen and Fishbein, 1975). Intention not only shows paths that guide a person to behave in certain ways, but also reflects actions. Thus, intention can be considered as a motivational factor that influences the behavior and the severity of a person's attempt to try and how much effort they plan to use in carrying out such behavior (Hisrich et. al., 2008).

The Need for Achievement. The concept of need for achievement derived from the theory of cognitive motivation. This theory is based on the birth of a requirement. Motif is defined as an internal psychological boost that helped the emergence of certain patterns of behavior (Friedman and Schustack, 2008). In other words, motivation leads one's behavior as it is pursued to achieve a set of goals based on certain performance level to accomplish tasks. Motivation functions with ability and environmental factors also considered as critical factors for target achievements (Mitchell, 1982).

The Concept of Self-efficacy. Individual cognitive processes differ depending on the uniqueness of personal characteristics. According to Bandura (1997) self-efficacy is the belief in individual's ability to perform tasks or actions necessary to achieve certain results. Self-efficacy is basically the result of cognitive processes such as decision, belief, or expectation concerning the extent to which the individual estimates his ability to perform tasks or acts to achieve the desired results. Perceptions of self-efficacy in each individual develops from gradual achievement of specific skills and experience continuously.

The Concept of Entrepreneurship Education. Entrepreneurship education includes activity in the process of learning and training that provide sufficient knowledge of entrepreneurship and entrepreneurial activity. According to Bell (2008) entrepreneurship 
education traditionally focuses on the business plan, how to obtain financing, the process of enterprise development and small business management.

The Concept of Gender Stereotype. Gender stereotype is an overview of the characteristics (labels) that standardized by one group (standardized mental picture). Gender is regarded as a social control mechanism that forms the basis of the behavior of men and women. Negative stereotypes can produce discrimination against one group, in the form of racism or sexism. Furthermore, this view affects one's intention to entrepreneurship.

\section{METHODS OF RESEARCH}

This research is descriptive and developed with qualitative approach. Descriptive analysis method is to provide an overview of the demographics of respondents and descriptions of the studied variables based on students' responses on questionnaires.

Research population consists of 1,952 students that enrolled in entrepreneurship classes in all faculties at Tadulako University. These include: The Faculty of Teaching and Education, The Faculty of Mathematics and Science, The Faculty of Engineering, The Faculty of Social and Political Schience, The Faculty of Economics, and The Faculty of Law. By applying sample random method and Slovin method, this study selected 387 students as respondents.

The study uses primary and secondary data. Primary data is collected through questionnaires, interviews, and also observations. Secondary data is collected from the Office of Student Affairs and Academic of each faculty and from The BAAK office of Tadulako, statistics, and other supporting documents/articles that are related to the study.

\section{RESULTS AND DISCUSSION}

Based on the survey, it is revealed that 99.7 percent or 386 respondents aged between 18 to 25 years old. At this age, students need a comprehensive understanding of an issue prior making important decisions, including the decision to entrepreneurship. The stage of human development confirms that at this age, the youth enter the stabilization phase of their life establishment (Yusuf, 2012: 27).

Related to their interests after graduation, 290 respondents or $74.9 \%$ expressed their interests to engage in the labor market; 50 people or $12.9 \%$ plan to continue their study to magister programs; and as many as 42 people or $10.9 \%$ of respondents did not answer. While $1.3 \%$ or 5 respondents answered that they will not enter the job market after graduating. From these data, a total of 290 respondents who indicated a willingness to work after graduation can be directed to self-employment with their creativity and knowledge. Students are expected to have a stronger readiness to entrepreneurship than do a job hunt or work as an employee.

Table 1 - Respondents' Perceptions on Entrepreneurial Intentions

\begin{tabular}{|c|c|c|c|c|c|c|c|c|c|c|c|}
\hline \multirow{2}{*}{ Indicators } & \multicolumn{2}{|c|}{1} & \multicolumn{2}{|c|}{2} & \multicolumn{2}{|c|}{3} & \multicolumn{2}{|c|}{4} & \multicolumn{2}{|c|}{5} & \multirow{2}{*}{ Mean } \\
\hline & $f$ & $\%$ & $f$ & $\%$ & $f$ & $\%$ & $f$ & $\%$ & $f$ & $\%$ & \\
\hline Desire to become an entrepreneur & 4 & 1.03 & 14 & 3.62 & 79 & 20.41 & 118 & 30.49 & 172 & 44.44 & 4.14 \\
\hline Desire to manage personal business & 5 & 1.29 & 14 & 3.62 & 96 & 24.81 & 161 & 41.60 & 111 & 28.68 & 3.93 \\
\hline Convenience & 4 & 1.03 & 31 & 8.01 & 139 & 35.92 & 119 & 30.75 & 94 & 24.29 & 3.69 \\
\hline Capital leverage & 6 & 1.55 & 11 & 2.84 & 15 & 3.88 & 138 & 35.66 & 217 & 56.07 & 4.42 \\
\hline Freedom of working & 5 & 1.29 & 17 & 4.39 & 64 & 16.54 & 151 & 39.02 & 150 & 38.76 & 4.10 \\
\hline Independency & 5 & 1.29 & 10 & 2.58 & 45 & 11.63 & 98 & 25.32 & 229 & 59.17 & 4.39 \\
\hline Resource's utilization & 3 & 0.78 & 8 & 2.07 & 79 & 20.41 & 177 & 45.74 & 120 & 31.01 & 4.04 \\
\hline Parental support & 5 & 1.29 & 11 & 2.84 & 92 & 23.77 & 137 & 35.40 & 142 & 36.69 & 4.03 \\
\hline Future security & 3 & 0.78 & 13 & 3.36 & 102 & 26.36 & 138 & 35.66 & 131 & 33.85 & 3.98 \\
\hline Mean & & & & & & & & & & & 4.08 \\
\hline
\end{tabular}

Table 1 shows perceptions of respondents about their entrepreneurial intentions based on several aspects namely: desire to become an entrepreneur, satisfaction towards own businesses, convenience, capital, freedom to work, independency, resource utilization, parent support, and future security. The most dominant factor of entrepreneurial intention is 
the availability of venture capital. The availability of financial resources is considered a key requirement in entrepreneurial activity. On the other hand, indicator dependency is at the second place and shows a mean of 4.39. Independence in entrepreneurship is believed as the non-financial trigger for entrepreneurial intentions.

Table 2 - Respondents' Perceptions on the Need for Achievement

\begin{tabular}{|c|c|c|c|c|c|c|c|c|c|c|c|}
\hline \multirow{2}{*}{ Indicators } & \multicolumn{2}{|c|}{1} & \multicolumn{2}{|c|}{2} & \multicolumn{2}{|c|}{3} & \multicolumn{2}{|c|}{4} & \multicolumn{2}{|c|}{5} & \multirow{2}{*}{ Mean } \\
\hline & $f$ & $\%$ & $f$ & $\%$ & $f$ & $\%$ & $f$ & $\%$ & $f$ & $\%$ & \\
\hline Performance & 6 & 1.55 & 2 & 0.52 & 38 & 9.82 & 179 & 46.25 & 162 & 41.86 & 4.26 \\
\hline Risk taking & 5 & 1.29 & 5 & 1.29 & 34 & 8.79 & 197 & 50.90 & 146 & 37.73 & 4.22 \\
\hline Optimistic & 6 & 1.55 & 7 & 1.81 & 66 & 17.05 & 173 & 44.70 & 135 & 34.88 & 4.10 \\
\hline Improving unsatisfied performance & 5 & 1.29 & 4 & 1.03 & 22 & 5.68 & 151 & 39.02 & 205 & 52.97 & 4.41 \\
\hline The ability to run business & 4 & 1.03 & 15 & 3.88 & 137 & 35.40 & 150 & 38.76 & 81 & 20.93 & 3.75 \\
\hline Entrepreneurship is acceptable & 3 & 0.78 & 10 & 2.58 & 152 & 39.28 & 147 & 37.98 & 75 & 19.38 & 3.73 \\
\hline \multicolumn{11}{|c|}{ Mean } & 4.08 \\
\hline
\end{tabular}

The most prominent indicator of 'the need for achievement' as shown in Table 2 is the effort to improve unsatisfied results with a mean of 4.41. This indicates a strong determination of individuals to improve and strengthen their commitment to perform better in the field of their interests. Performing well in the job completion shows a mean of 4.26 , which is also classified high category. This means that most of respondents have the ability to perform their job satisfactorily.

Another indicator in 'the need for achievement' is 'entrepreneurship is acceptable' that shows a mean of 3.73. This means that entrepreneurship is accepted as one of decent jobs not only because it is 'considered' beneficial but also, engaging as entrepreneurs will open chances to create job opportunities for other people. Thus, financial independent will lead to personal empowerment and wealth improvement. Overall, the results indicate that all respondents concerned that success in self-employment must be supported by a commitment to meet the needs of achievement.

Table 3 - Respondents Perceptions on Self-efficacy

\begin{tabular}{|c|c|c|c|c|c|c|c|c|c|c|c|}
\hline \multirow{2}{*}{ Indicators } & \multicolumn{2}{|c|}{1} & \multicolumn{2}{|c|}{2} & \multicolumn{2}{|c|}{3} & \multicolumn{2}{|c|}{4} & \multicolumn{2}{|c|}{5} & \multirow{2}{*}{ Mean } \\
\hline & $f$ & $\%$ & $f$ & $\%$ & $f$ & $\%$ & $f$ & $\%$ & $f$ & $\%$ & \\
\hline Managing people & 3 & 0.78 & 33 & 8.53 & 130 & 33.59 & 155 & 40.05 & 66 & 17.05 & 3.64 \\
\hline Ability to innovate & 2 & 0.52 & 11 & 2.84 & 79 & 20.41 & 179 & 46.25 & 116 & 29.97 & 4.02 \\
\hline Seeking Market Information & 4 & 1.03 & 16 & 4.13 & 118 & 30.49 & 195 & 50.39 & 54 & 13.95 & 3.72 \\
\hline Seeking for funding & 5 & 1.29 & 18 & 4.65 & 116 & 29.97 & 192 & 49.61 & 56 & 14.47 & 3.71 \\
\hline Responding to others & 2 & 0.52 & 13 & 3.36 & 103 & 26.61 & 188 & 48.58 & 81 & 20.93 & 3.86 \\
\hline The ability to face uncertainty & 5 & 1.29 & 21 & 5.43 & 148 & 38.24 & 159 & 41.09 & 54 & 13.95 & 3.61 \\
\hline Managing Resources & 2 & 0.52 & 14 & 3.62 & 113 & 29.20 & 195 & 50.39 & 63 & 16.28 & 3.78 \\
\hline Skills needed & 2 & 0.52 & 15 & 3.88 & 130 & 33.59 & 161 & 41.60 & 79 & 20.41 & 3.78 \\
\hline Taking Risks & 2 & 0.52 & 13 & 3.36 & 103 & 26.61 & 196 & 50.65 & 73 & 18.86 & 3.84 \\
\hline The ability to adverse & 4 & 1.03 & 9 & 2.33 & 77 & 19.90 & 160 & 41.34 & 137 & 35.40 & 4.08 \\
\hline & & & & lean & & & & & & & 3.80 \\
\hline
\end{tabular}

The description of respondents' self-efficacy as described in Table 3 above reflects students' confidence of their ability to work. A high rate of self-efficacy can generate initiative and perseverance to work, so as to have a positive impact by increasing performance in general. By contrast, the low self-efficacy tends to degrade performance. People with high self-efficacy tend to be more initiative, creative, and innovative compared to those with have low self-efficacy. Self-efficacy influences the choice of action and effort exerted to achieve business success. Self-confidence and trust in the ability of working based on the hard work and dedication positively affect entrepreneurial intentions.

Entrepreneurial education includes learning activities that provide sufficient knowledge of entrepreneurship and entrepreneurial activity. Programs in entrepreneurial education in Tadulako University include: (1) Entrepreneurship Culture Development Program that covers activities of entrepreneurship courses, entrepreneurial internships, job training, business consulting and job placement, and new entrepreneurs incubator (2) Student Creativity Program (3) Retooling Program, and (4) Student Entrepreneurial Program.

Students' responses on entrepreneurship education as seen in Table 4 shows their potentials as successful entrepreneurs. Respondents realize that the ability to communicate, 
creativity, and the ability to manage business, as dominant capacities that a good entrepreneur should apply. By recognizing the importance of entrepreneurship education and its impact, the participants of entrepreneurship courses showed their approval and provide positive feedback.

Table 4 - Respondents' Perceptions on Entrepreneurial Education

\begin{tabular}{|c|c|c|c|c|c|c|c|c|c|c|c|}
\hline \multirow{2}{*}{ Indicators } & \multicolumn{2}{|c|}{1} & \multicolumn{2}{|c|}{2} & \multicolumn{2}{|c|}{3} & \multicolumn{2}{|c|}{4} & \multicolumn{2}{|c|}{5} & \multirow{2}{*}{ Mean } \\
\hline & $f$ & $\%$ & $\mathrm{~F}$ & $\%$ & $f$ & $\%$ & $\mathrm{~F}$ & $\%$ & $f$ & $\%$ & \\
\hline Self-confidence & 5 & 1.29 & 9 & 2.33 & 43 & 11.11 & 184 & 47.55 & 146 & 37.73 & 4.18 \\
\hline Ability to managing business & 8 & 2.07 & 6 & 1.55 & 32 & 8.27 & 180 & 46.51 & 161 & 41.60 & 4.24 \\
\hline Enhance the ability to communicate & 5 & 1.29 & 9 & 2.33 & 34 & 8.79 & 173 & 44.70 & 166 & 42.89 & 4.26 \\
\hline Experience & 6 & 1.55 & 5 & 1.29 & 44 & 11.37 & 177 & 45.74 & 155 & 40.05 & 4.21 \\
\hline Creativity & 5 & 1.29 & 10 & 2.58 & 32 & 8.27 & 177 & 45.74 & 163 & 42.12 & 4.25 \\
\hline Needed materials & 3 & 0.78 & 6 & 1.55 & 56 & 14.47 & 169 & 43.67 & 153 & 39.53 & 4.20 \\
\hline Applied method & 6 & 1.55 & 11 & 2.84 & 81 & 20.93 & 177 & 45.74 & 112 & 28.94 & 3.98 \\
\hline Applicative discussion & 5 & 1.29 & 10 & 2.58 & 100 & 25.84 & 180 & 46.51 & 92 & 23.77 & 3.89 \\
\hline Strengthening entrepreneurial desire & 5 & 1.29 & 9 & 2.33 & 88 & 22.74 & 162 & 41.86 & 123 & 31.78 & 4.01 \\
\hline \multicolumn{11}{|c|}{ Mean } & 4.13 \\
\hline
\end{tabular}

Table 5 - Respondents' Perceptions on Gender Stereotype

\begin{tabular}{|c|c|c|c|c|c|c|c|c|c|c|c|}
\hline \multirow{2}{*}{ Indicators } & \multicolumn{2}{|c|}{1} & \multicolumn{2}{|c|}{2} & \multicolumn{2}{|c|}{3} & \multicolumn{2}{|c|}{4} & \multicolumn{2}{|c|}{5} & \multirow{2}{*}{ Mean } \\
\hline & $f$ & $\%$ & $f$ & $\%$ & $f$ & $\%$ & $f$ & $\%$ & f & $\%$ & \\
\hline Men and women have the same ability & 8 & 2.07 & 22 & 5.68 & 103 & 26.61 & 106 & 27.39 & 148 & 38.24 & 3.94 \\
\hline The same access to entrepreneurship & 6 & 1.55 & 15 & 3.88 & 89 & 23 & 138 & 35.66 & 139 & 35.92 & 4.01 \\
\hline Women more courageous & 21 & 5.43 & 49 & 12.66 & 175 & 45.22 & 81 & 20.93 & 61 & 15.76 & 3.29 \\
\hline Men are less motivated to entrepreneurship & 49 & 12.66 & 104 & 26.87 & 155 & 40.05 & 56 & 14.47 & 23 & 5.94 & 2.74 \\
\hline Women are tougher & 30 & 7.75 & 58 & 14.99 & 177 & 45.74 & 74 & 19.12 & 48 & 12.4 & 3.13 \\
\hline Women more Diligent & 19 & 4.91 & 46 & 11.89 & 162 & 41.86 & 104 & 26.87 & 56 & 14.47 & 3.34 \\
\hline Women more Independent & 20 & 5.17 & 56 & 14.47 & 172 & 44.44 & 88 & 22.74 & 51 & 13.18 & 3.24 \\
\hline Women have roles in educating and parenting & 13 & 3.36 & 19 & 4.91 & 80 & 20.67 & 122 & 31.52 & 153 & 39.53 & 3.99 \\
\hline Men primarily take decisions in the family & 11 & 2.84 & 16 & 4.13 & 53 & 13.7 & 113 & 29.2 & 194 & 50.13 & 4.20 \\
\hline Women have important roles in family's economy & 52 & 13.44 & 68 & 17.57 & 125 & 32.3 & 79 & 20.41 & 63 & 16.28 & 3.09 \\
\hline Women Entrepreneurs can increase family welfare & 12 & 3.1 & 28 & 7.24 & 147 & 37.98 & 100 & 25.84 & 100 & 25.84 & 3.64 \\
\hline \multicolumn{11}{|l|}{ ( } & 3.51 \\
\hline
\end{tabular}

Respondents' perceptions of gender stereotypes as shown in Table 5 above shows their understanding of a set of demands or the value derived from the social formation that includes the appropriateness behavior for men and women. The table also explains that the most prominent indicators of gender stereotypes is 'men primarily take decisions in the family' with the highest mean of 4.20 . This result demonstrates a strong patriarchal understanding among young generations. In this case, men are still considered as the competent authorities in the decision making process over women. Men as the final decision makers. Yet, participation of women in decision-making in some areas has started to increase as women are more involved in family welfare issues. The general perceptions of respondents over gender stereotypes reflect their understanding that entreprenurial activities are gendered matter and cannot be separated from the local culture and values.

\section{DISCUSSION OF RESULTS}

The intention of students of Tadulako University to engage in entrepreneurial activities is relatively high. In this case, the students envisioned themselves to be entrepreneurs but slightly unsure of the business security. They have doubts in terms of business sustainability and the ability of the business to ensure their own future. Consideration of the availability of capital as an indicator of the business establishment also concern the respondents. The majority of them consider that before starting a business, they must have sufficient capital. Financial security is required to open business and the top reason to maintain their existence in entreprenurial activities. In this case, most of respondents do not fully understand that reliance on capital can also lead to bancruptcy because it is not the only indicator of success. A lot of businesses with abundant capital became bankrupt because the funds are not properly managed.

Apart from that, parental support and role models also appear to have a significant impact in developing students' entrepreneurial intentions. Students' early exposure to 
entrepreneurship by helping parents with their businesses and the perceived success of their parents' experience can boost the entrepreneurial intention. As many as 100 respondents come from entrepreneurial family background and they relatively expressed a higher intention to start their own businesses. This result is in line with the findings of Linan et. al. (2005), Mueller (2006), and Aslam et.al (2012) that suggest that individuals with entrepreneurial role models tend to be entrepreneurs. Family background provides the youth with the opportunity to acquire certain business skills, confidence, experience and vision, all of which contribute to inclination to start a new business. Positive parental entrepreneurial experiences and supports positively impact students' entrepreneurial intentions. Since the students have positive attitudes and self-efficacy toward entrepreneurial practices, they tend to imitate their parents' successfulness. Through their self-efficacy, the students will be able to imitate that behavior and perceive entrepreneurial career (Aslam et.al, 2012). Further, Aslam's findings confirm that Ajzen's theory is useful in predicting the behavioral mindset of students.

The other element that the respondents mostly like about being an entrepreneur is independency. Being independent in managing business reflects their flexibility in designing and implementing their creativity without being limited by the orders and instructions of the 'bos' that, in most cases, tend to block their freedom of thought. In addition, respondents also optimistic that the autonomy in managing the resources will open up space for broader innovative thoughts. Independence in thinking and behaving is realized by most respondents as the biggest driving force for them to develop their own businesses.

One of the positive characters that need to be developed in the practice of entrepreneurship is work determination. Their desire to continuously improve the unsatisfactory work can lead them to success. This illustrates the unyielding nature and always assumes good faith on their businesses. This quality is found in dimension the need for achievement'. One of the conditions of success is the continuing effort to evaluate and improve work performance. Determination to work better is able to bring these students to the state in which they were able to maintain consistency in terms of a stable work, that they seek to do their job well. This quality relates to the concept of self-efficacy (Fiedman and Schustack, 2008). One indicator in 'self-efficacy' emphasizes the ability of entrepreneurs to fight back in the time of failure.

Furthermore, the courage to bear the risk is also a character of successful entrepreneurs. Risk taking, as a tendency of an individual to take risks, cannot be separated from entrepreneurships. An entrepreneur who wants to succeed must dare to try different things and implement new breakthrough to be a pioneer. Though in the process they have to use more resources, but they are optimistic that in order to achieve success, they can face the risks. People who tolerate higher risks are more inclined to entrepreneurship.

Also, respondents realize that being entrepreneurs gives them additional value as good citizens. Their involvement in independent businesses not only provides financial advantages but also enables them to open employment for others. In all, entrepreneurs also create opportunities for lifetime learning. Increased personal capabilities provide a better opportunity to be involved in the decision-making process, both within the family and society. These are some of the underlying reasons of the acceptance of self-employment as one alternative employment. In difficult times, innovativeness and risk-taking propensity emerged consistently that making significant contributions on entrepreneurial intentions.

Another interesting finding is that respondents show higher levels of dispositional optimism. Over the challenge of being entrepreneurs, having an optimistic outlook is important. They believe in their ability on communication skills, which enables them to build connections with other parties and internally, strengthen relationships with working partners.

Taking entrepreneurship classes that enable students to build and develop their entrepreneurial interest through theory and practices, also a factor that make a significant impact on the intention of students in entrepreneurships. Yet, they suggest that the university should develop learning materials that enable them to have applicative and interactive discussions and entrepreneurial practices both on and off campus. This finding suggests that entrepreneurship programs should educate students for entrepreneurship rather than about 
entrepreneurship (Kirby, 2005). The majority of students consider the entrepreneurship class is helpful in finding new business ideas. As innovation and creativity are related with the experiential activities, students should also be encouraged to get involved with some internships activities, new experiences, and art events. Although such activities need highqualified tutors, the idea can be woven into university's curriculum. Following this, course characteristics and teaching methods also need to be improved. Presenting entrepreneurship knowledge is not sufficient to influence student's intentions. The University of Tadulako should design an integrated approach that link classroom-teaching activities with real life experiences. Experiential learning and practical experience that stimulate more experimentation and creative thinking will motivate students to be engaged as active learners.

Another interesting finding of this study is highlighted in the variable of gender stereotype. The majority of respondents give low point on indicator 'men lack of motivation to be entrepreneurs'. This proves that most of the respondents, which are females, consistently think that men have a better motivation in entrepreneurships compared to women. Therefore, women are likely to have less favorable intentions in entrepreneurships (Aslam et.al, 2012). These young men and women associate entrepreneurs with stereotypically masculine characteristics and their disagreement on men's lack of motivation to be entrepreneurs. Although the number of women entrepreneurs has increased dramatically in recent years, it seems that entrepreneurship is still being regarded as a male-dominated field (Mueller and Thomas, 2000; De Bruin et al. 2006). Especially, men are still regarding as primary decision makers in the family and social spaces.

\section{CONCLUSION}

This study has identified some triggering factors of Tadulako students' entrepreneurial intentions. Overall, the findings call for a holistic approach to understanding entrepreneurial intention that includes the dimensions of the need for acheivement, self-efficacy, entrepreneurship education, and gender stereotypes among students in Tadulako University.

An important finding of this study is that the students of Tadulako University show relatively strong intentions to start their own new venture. This supports by their personal attitudes toward becoming successful entrepreneurs. In addition, entrepreneurship education is regarding as an important tool in developing students' entrepreneurial intentions. However, cultural norms, for instance gender stereotype still strongly exist and influence the student's perspective on entrepreneurial participations. This leads to a consideration that several universal or culture-specific factors should be adjusted so that the participation of men and women in managing businesses independently can be increased. By doing so, the discrepancy between entrepreneurial attitude and intention can be minimized.

\section{REFERENCES}

1. Adda, Harnida; Wahyuningsih; Husnah; and Wirastuti, Wiri. 2014. Regional Manpower Planning of Central Sulawesi Province 2014-2016. Unpublished Document. Cooperation with the Office of Manpower and Transmigration Central Sulawesi.

2. Aslam, Tahseen Mahmood; Awan, Ahmed Sher; Khan, Tariq Mahmood. 2012. Entrepreneurial Intentions among University students of Punjab a Province of Pakistan. International Journal of Humanities and Social Science. 2. 14.114-120.

3. Ajzen, I. 1991. The Theory Of Planned Behavior. Organizational Behavior and Human Decision Processes. 50. 179-211.

4. Ajzen, I. and Fishbein, M. 1975. Belief, Attitude, Intention and Behavior: An Introduction to Theory and Research, Addison Wesley Publishing Company Inc, Menlo Park, California.

5. Bandura, A. 1997. Self-Efficacy: The Exercise of Control, W.H. Freeman and Company, New York. 
6. Bell, Joseph, R. 2008. Utilization of Problem Based-Learning in an Entrepreneurship Business Planning Course. New England Journal of Entrepreneurship. 11.1. 53-61.

7. Bird, B. 1988. Implementation Entrepreneurial Ideas: The Case for Intention, Academy of Management Review 13. 3. 442-452

8. Darmaningtyas. 2008. Makin Tinggi Pendidikan Makin Gampang Menganggur. $\mathrm{http} / / \mathrm{www} / \mathrm{kompas}$.com. Retrieved accessed on 13 Oktober 2016.

9. De Bruin, A., Brush, C. G., \& Welter, F. 2006. Introduction To The Special Issue: Towards Building Cumulative Knowledge On Women's Entrepreneurship. Entrepreneurship Theory and Practice. 30. 585-592.

10. Fiedman, H.S and Schustack. 2008. Theories of Classical Personality and Modern Research, Ikarini F.D, Maria. H, dan Andreas P.P. (Eds). Kepribadian Teori Klasik dan Riset Modern, Edisi Ketiga , Penerbit Erlangga.

11. Friedman, Barry; Aziz, Nergis; Keles, Ibrahim; Sayfullin, Salavat. 2012. Predictors of Students' Desire to be an Entrepreneur: Kyrgyzstan, Georgia, and the US. Eurasian Journal of Business and Economics. 5. 9. 29-140.

12. Hisrich, R. D., Peters, P. M., \& Shepard, D. A. (2008). Entrepreneurship. Singapore: Mc Graw Hill International Edition.

13. Indarti dan Rostiani. 2008. Intensi Kewirausahaan Mahasiswa: studi perbandingan antara Indonesia, Jepang dan Norwegia, Jurnal Ekonomi \& Bisnis Indonesia, 23. 4. 369-384.

14. Kautonen, T., Tornikovski, E. T., Kibler, E. 2011. Entrepreneurial Intentions In The Third Age: The Impact of Perceived Age Norms. Small Bus Econ. 37. 219-234.

15. Kirby, D. A. 2005. Entrepreneurship Education: Can Business Schools Meet The Challenge? San Francisco Proceedings of the 2005. San Francisco-Silicon Valley Global Entrepreneurship Research Conference. 173-193.

16. Kolvereid, L., \& Isaksen, E. 2006. New Business Start-Up And Subsequent Entry Into Self-Employment. Journal of Business Venturing, 21. 6. 866-885.

17. Krueger, Norris and Carsrud, Alan. 1993. Entrepreneurial Intentions: Applying The Theory of Planned Behaviour. Entrepreneurship and Regional Development. 5. 4. 315330.

18. Krueger, Norris; Reilly, Michael, and Carsrud, Alan. 2000. Competing Models of Entrepreneurial Intentions, Journal of Business Venturing. 15. 5-6. 411-432.

19. Lakovleva, T., Kolvereid, L., \& Stephan, U. 2011. Entrepreneurial Intentions In Developing And Developed Countries. Education + Training, 53. 5. 353-370.

20. Linan, Fransisco. 2004. Intention Based Model of Entrepreneurship Education, http.//www.congresso.us.es/gpyde/downloa/a9.pdf. Retrieved on September 11, 2016.

21. Linan, F., Rodriguez-Cohard, J. C., \& Rueda-Cantuche, J. M. 2005. Factors Affecting Entrepreneurial Intention Levels. Paper presented at the 45th Congress of the European Regional Science Association. Amsterdam.

22. Mitchell, T. R. 1982. Motivation: New Directions for Theory, Research, And Practice. Academy of Management Review, 7, 80-88.

23. Mueller, P. 2006. Entrepreneurship in The Region: Breeding Ground For Nascent Entrepreneurs? Small Business Economics, 27. 1. 41-58.

24. Mueller, S. L., \& Thomas, A. S. 2000. Culture And Entrepreneurial Potential: A Nine Country Study Of Locus Of Control And Innovativeness. Journal of Business Venturing. 16. 51-75.

25. Ozaralli, Nurdan and Rivenburgh, Nancy, K. 2016. Entrepreneurial Intention: Antecedents to Entrepreneurial Behavior in the U.S.A. and Turkey. Journal of Global Entrepreneurship Research. DOI: 10.1186/s40497-016-0047-x. 6-3.

26. Yusuf, Syamsu. (2012). Psikologi Perkembangan Anak dan Remaja. Bandung. Remaja Rosdakarya. 